\title{
Development of Optical Learning Modules Based on Critical Thinking Skills
}

\author{
Mardiana Afriany Simatupang 1,* Motlan ${ }^{2, *}$ Juniastel Rajagukguk ${ }^{3}$ \\ ${ }^{1}$ Physics Education Program, Postgraduate School, Universitas Negeri Medan \\ ${ }^{2,3}$ Department of Physics, Faculty of Mathematics and Natural Science, Universitas Negeri Medan \\ *Corresponding author. Email: dianasimatupang1992@gmail.com
}

\begin{abstract}
The Atlantis Press This research is a development research that aims to: (1) the feasibility of an optical module based on critical thinking skills on the problem solving abilities of high school students developed. (2) for the practicality of the optical module based on critical thinking skills to the problem solving abilities of high school students developed. (3) for the objectivity of using optical modules based on critical thinking skills to high school students' problem solving abilities. The subjects of this study were students of class XI Science SMA Raksana Medan and several experts at each stage of development. A preliminary study was conducted to find out the material and indicators that will be presented in the module. The preparation of the module was carried out based on the module preparation guidelines from the 2008 Ministry of National Education. The validation results showed that the module on optical material had met the appropriateness standards of content, media, and language. The results of the field trial showed that the module was included in the good category in terms of readability, interest, and student responses. The modules that have been developed are then analyzed for their effectiveness. The research data was obtained through a critical thinking test of optical material on students' problem solving abilities. The results of the effectiveness test showed that the students had met the minimum completeness criteria in critical thinking skills, while the tendency towards problem solving skills after using the optical module did not show any significant changes.
\end{abstract}

Keywords: critical thinking, module, problem solving ability.

\section{INTRODUCTION}

The Optical concepts tend to be mathematical, in optical concepts we will find problems that require analytical skills. Analysis in Bloom's taxonomy is the ability to detail a situation or knowledge according to smaller or more decomposed components and understand the relationship between one part and another. By observing the teaching and learning process in the classroom, it was found that the problem solving activity of students in the learning process was low. The material is delivered through the lecture method, discusses sample questions and provides exercises in the same form as the examples. According to Pastel (in Lee, 1998) that teaching conventional methods by relying on conveying information, demonstrating problem solving, and providing opportunities for students to try problem solving with the same type of problem as the example does not help students to develop their problem solving skills.

\subsection{Introduction Learning Module}

The learning module is the smallest unit of teaching and learning program that is studied by students themselves individually or is taught by students to themselves (Winkel, 2009). According to Mulyasa (2006) the module is an independent learning package that includes a series of learning experiences that are planned and systematically designed to help students achieve learning goals. Furthermore, Purwanto (2007), added that learning modules are teaching materials that are systematically designed based on a certain curriculum and packaged in the form of the smallest learning unit that allows it to be studied independently in a certain time unit.

\subsection{Characteristics Learning Module}

Some of the characteristics of the learning model include: 1. Self Instructional is an important characteristic in the module with this character the possibility of someone learning independently and not depending on other parties. To fulfill the self-instruction 
character, the module must: 1) contain clear learning objectives, and be able to describe the achievement of Competency Standards and Basic Competencies; 2) Loading learning materials that are packaged in small or specific activity units so that they are easy to learn thoroughly; 3) There are examples and illustrations that support the clarity of the presentation of learning materials; 4) There are practice questions for assignments and the like that make it possible to measure student mastery; 5) Contextual, namely the material presented is related to the atmosphere of the task or the context of the activities and the environment of students. 6) Using simple and communicative language; (7) There is a summary of learning materials; 8) There is an assessment instrument that allows students to conduct self-assessment (self-assessment); 9) There is feedback on the assessment of students so that students know the level of mastery of the material; 10) There is information about references or enrichment or references that support the intended learning material.

\subsection{Module Components}

According to Sungkono (2009) the main components that need to be available in the module, namely: 1) The subject review contains a general description of the overall subject matter content which includes a description of the subject matter of the use of basic competencies and other supporting materials; 2) Instructional learning instructions contain an explanation of the various activities that must be carried out, the tools that need to be provided and the procedures to be carried out; 3) The preliminary introduction of a module is the opening of learning 1 module that contains things such as the scope of the content of the module in the form of a brief description of the indicators to be achieved, a description of the initial behavior, the relevance of the material, the order of the module presentation items and learning instructions; 4) The learning activities in this section contain subject matter that must be mastered by students in the presentation of the module material, paying attention to two basic elements, namely the description in the presentation of the material and examples; 5) Exercise; exercises are various forms of learning activities that must be carried out by students after reading the previous description of the purpose of the exercise so that students really learn actively and finally master the concepts being discussed in the activity; 6) Exercise answer signs use these signs to direct students' understanding of the expected answers to questions or exercises to support the achievement of learning competencies; 7) Summary: the summary is the essence of the description of the material presented in the learning activities of a module whose function is to conclude and strengthen the learning experience (content and process) that can condition the growth of new concepts or schemes in students' minds; 8) Formative Text: formative test is a test to measure students' mastery after a subject has been presented in a learning activity ends; 9) Formative Test Answer Key;
The answer key is generally placed at the very end of a module. The aim is for students to know the level of mastery of the content of the learning activity; and 10) Feedback and Follow-up: contains activities that students have to do on the basis of their formative tests. Students are given instructions to carry out further activities.

\subsection{Advantages of Learning by using Modules}

Mulyasa (2010) states: 1) Focusing on students' individual abilities because in essence they have the ability to work alone and are more responsible for their actions; 2) There is control over learning outcomes through the use of competency standards in each module that must be achieved by students. According to Tjipto (1991) revealed several advantages obtained if learning to use the module, among others: 1) Student motivation becomes higher; 2) Students find out more quickly the results of mastery of the concepts they have; 3) Students achieve results according to their abilities; 4) The learning load is evenly distributed throughout the semester; and 5) more efficient education.

\section{METHOD}

This study uses research and development methods.One of the media that pays attention to the basic stages of media development design that is simple and easy to understand is the ADDIE framework. This ADDIE consists of five phases, namely, Analysis, Design, Development, implementation, evaluation.

\section{RESULTS AND DISCUSSION}

\subsection{Analysis}

The first stage in the research and development procedure is to conduct a preliminary study by conducting curriculum analysis and analysis of student needs. This analysis stage is carried out on June 20-21, 2021. A preliminary study is carried out to determine the material and analyze needs as a basis for product preparation. The material used in this research and development is Optics because considering the many objects around us that are in the form of flat-sided shapes.

\subsection{Design}

a. Collecting books related to teaching materials that will be developed include a module based on the ability to think critically on the ability of problems with light and optical instruments by Diana Simatupang.

b. Collecting books related to teaching materials that will be developed include a module based on the ability to think critically on the ability of problems with light and optical instruments by Diana Simatupang. 


\subsection{Development (Product Draft Development)}

a. Module Editing

After the module draft has been compiled, the module draft is consulted with the supervisor with the aim of getting suggestions for improvements and improvements. The draft module that has been consulted is then revised according to the advice of the supervisor, then consulted again until the draft module is approved for validation to the validator.

\section{b. Module Validation}

The product validity test was obtained from the results of the expert validators' assessment of the feasibility of the Critical Thinking Ability-Based Optical physics module that had been developed. Product validation was carried out using a validation questionnaire for lecturers and teachers. Validation was obtained from 4 validators consisting of 3 lecturers of the Faculty of Mathematics and Natural Sciences who are competent in their fields, namely Drs. Togi Tampubolon, M.Sc., Ph.D., Dr. Ridwan A. Sani, M. Si, Nora Hawari Daulay, M.Pd and 1 physics teacher at the Raksana Private High School Medan, namely Mei Yunina Arianti S.Pd.

\subsection{Evaluation}

The evaluation phase includes formative evaluation and summative evaluation. Formative evaluation is carried out at each stage of the ADDIE which is used as the completion and validity of the module. While the summative evaluation is carried out at the end of the stage to determine the practicality and effectiveness of the module. The research data analyzed at the formative evaluation stage are the results of the module assessment and suggestions from the validator.

The research data analyzed at the summative evaluation stage were the results of the student and teacher response sheets to the module, the pretest and posttest results of students' critical thinking skills before and after using the developed module.

The results of the module effectiveness test show that students critical thinking skills have increased significantly from before using the module (pretest) to after using the module (posttest) from an average value of 52.03 to 89.75 . This happens because learning uses a physics module based on critical thinking skills, where students can be actively involved learning so that they get a learning experience to discover optical concepts through their own understanding. This is in line with the statement of Trianto and Suseno (in Trianto and Suseno, 2017:229) which states that critical thinking skills are learning activities that involve maximally all students abilities to search for and investigate something systematically, critically, logically, and analytically so that they can formulate their own findings with confidence.
Table 1. 10 T-Test Calculation Results Mean Difference

\begin{tabular}{|l|l|l|}
\hline Source of Variation & Pretest & Posttest \\
\hline $\mathrm{N}$ & 32 & 32 \\
\hline $\mathrm{Md}$ & 52,03 & 89,75 \\
\hline$\sum X^{2} \mathrm{~d}$ & 37,72 \\
\hline$t_{\text {hitung }}$ & 13980,47 \\
\hline $\mathrm{Db}$ & 10,047 \\
\hline$t_{\text {tabel }}$ & 31 \\
\hline
\end{tabular}

From the table above, the test results curve can be drawn as follows:

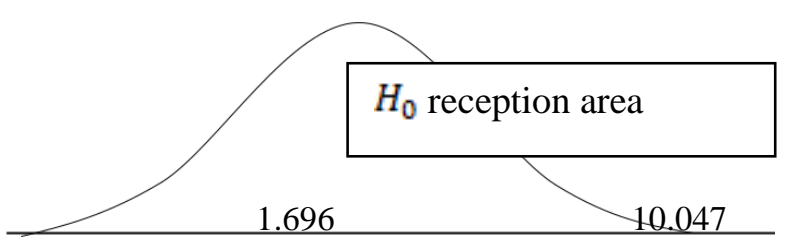

Figure 1. Average Difference Curve

Figure 1 average difference curve obtained $\mathrm{t}$ count $=10,047$ and $t$ table $=1,696$. Because 10.047 > 1.696 and $t$ arithmetic are in the Ho processing area, it can be concluded that the average critical thinking ability of students after using the module is greater than the average critical thinking ability of students before using the module.

\section{CONCLUSION}

Based on the results of the description and data analysis described in Chapter IV, the following conclusions can be drawn:

1. Based on the results of the module validation described in chapter IV, all aspects of the module assessment include content feasibility, presentation feasibility, critical thinking assessment, graphic feasibility, and language feasibility, quantitative data shows that the module developed has valid criteria with an average score. 3.36. This shows that the developed module is feasible to be tested in learning.

2. Based on the results of the responses of students and teachers, the results of the data analysis of the responses of students got the practical category with a value of 3.15. While the teacher's response analysis got a practical category with a value of 3.25 . This shows that the developed module helps teachers and students in learning.

3. Based on the calculation of the t-test, it shows that > i.e. $10.047>1.696$. This shows that the physics module 
based on critical thinking skills is effective for improving critical thinking skills.

\section{ACKNOWLEDGMENTS}

First of all, I would like to thank my teachers and professors at the university, who have given me gudance and support in writing this thesis. Then, i also thanks my friends for their motivation. Without their support, my thesis would not have been completed.

\section{REFERENCES}

[1] ALONSO - Finn.(1992). Dasar-dasar Fisika Universitas Edisi kedua (terjemahan). Penerbit Erlangga, Jakarta.

[2] David Halliday, Robert Resnick, Jearl Walker.Fisika Dasar (terjemahan).(2010). Penerbit Erlangga, Jakarta.

[3] Benjamin Crowell, Vibration and Wave. (2007). Fulerton, California. www.lightandmatter.com

[4] Benjamin Crowell, Electricity and Magnetism.(2007). Fulerton, California. www.lightandmatter.com

[5] Lilian Hoddeson, Teori Kuantum.(2004). Ilmu Pengetahuan Populer.PT Widyadara, Jakarta.

[6] J.M.Rueger.(1996). ElectronicDistance Measurement, UNSW, Australia.

[7] Sears, F.W-Zemarnsky, MW (1963). Fisika untuk Universitas (terjemahan). Penerbit Bina Cipta, Bandung

[8] Serway, R.A. dn Faughn, R. A. dan Faughn, J. S.(1999). College Physics,Harcourt Brace College Publishers. USA

[9] Sutanto, (1992).Penginderaan Jauh Jilid I.Gadjah Mada University Press, Yogyakarta 